\title{
Europe's Refugee Crisis in 2015 and Security Threats from the Baltic Perspective
}

\author{
Viljar Veebel $^{1} \&$ Raul Markus ${ }^{2}$ \\ ${ }^{1}$ Estonian National Defence College, Tartu, Estonia \\ ${ }^{2}$ University of Technology, Tallinn, Estonia \\ Correspondence: Viljar Veebel, Estonian National Defence College, Riia 12-402, Tartu 51013, Estonia. E-mail: \\ viljar.veebel@gmail.com
}

Received: October 31, 2015 Accepted: November 19, 2015 Online Published: November 29, 2015

doi:10.5539/jpl.v8n4p254

URL: http://dx.doi.org/10.5539/jpl.v8n4p254

\begin{abstract}
Recent developments in Europe starting with the Russia-Ukraine conflict and ending with the economic and political instability in Greece have given rise to instability in the European Union. Yet, none of the previous crises could be compared with the crisis concerning the current massive influx of refugees into the EU that challenges both solidarity and responsibility of the member states. In this context, it is extremely important to understand the actual security threats related to the refugee crisis, particularly for the Baltic countries that have linked their security with European Union and the NATO. Particularly in Estonia and in Latvia, the refugee crisis has been presented as a high security matter as possible rejection of the EU-migrant could lead to the country's isolation from the international community, the loss of the NATO security network and its exposure to the security threats from Russia. Alternative decision to accept the refugee quotas could on the other hand create challenges for internal security in terms of legitimacy of national governments and public support to refugee policy. In the light of recent terrorist attacks in France these questions seem even growingly important.
\end{abstract}

Keywords: European Union, refugee crisis, security, Baltic States

\section{Introduction}

After regaining their independence from the Soviet Union in 1991, the three Baltic countries have closely linked security of the region with a full integration with the European and transatlantic security networks, including political and economic integration with the European Union (EU) and military partnership in the North Atlantic Treaty Organization (NATO). The Baltic countries have considered membership in both organizations and solidarity among the member states as the main guarantee against possible threats from Russia. Almost all considerable security threats have been associated with their Eastern neighbor. For almost 25 years, the international co-operation and integration have provided these countries efficient "shelter" from the pressure Russia has come to impose on the independent states of the former Soviet Union.

However, in the light of the current refugee crisis and the opposition of the Baltic countries to the compulsory EU-migrant quotas, this concept of security has been challenged. Although Estonia, Latvia and Lithuania together with the Visegrád-countries have fulfilled their obligations set out in the Treaties of the EU, the Eastern European countries have been criticized particularly by Germany and France for not understanding the meaning and working of European solidarity, when not being ready to share the burden of the growing influx of refugees into Europe. As a possible penalty, reduction of the EU subsidies to the member states that oppose the EU-migrant quotas has been suggested by the German interior minister, Thomas de Maizière (The Economist 2015). In addition, financial penalties on the member states that are not willing to resettle refugees arrived initially in Italy and Greece are considered.

Paradoxically, the statements of the EU-politicians have been "amplified" by the local political elite in the Baltic countries, particularly in Latvia and Estonia. On the one hand, local politicians have warned the public that the Baltic countries could end up in an international isolation if people do not support refugee quotas. On the other hand, at least in Estonia, the leading part of the local political class has associated people's willingness to accept refugees with the country's responsibilities towards the NATO partners, using very broad argument "if you want to be protected by the allies, you have to accept refugees". Thus, the refugee crisis has been presented locally as 
a securitization, meaning that the opposition to compulsory migrant quotas has been described as an existential threat, because it could lead to the isolation of the Baltic countries from the international community, to the loss of the NATO security network and thereby to the countries' exposure to the security threats from Russia. Following the logic of the securitization theory (see, e.g. van Munster 2009; Šulovic 2010; Veebel, Namm and Tillmann 2014), the migration quotas are justified and should be considered as a priority, since extraordinary countermeasures should be used to handle existential threats.

However, as the authors see it, from the perspective of the Baltic countries security threats associated with the refugee crisis lies elsewhere. On the one hand, this conviction is based on the recent statements by principal figures of the NATO, e.g. Sir Adrian Bradshaw that different approach of the allies as regards the refugee crisis does not reduce the contributions of the NATO allies in collective security measures (Postimees 2015b). On the other hand, since the "Visegrad-countries" - Poland, the Czech Republic, Hungary and Slovakia - have opposed the mandatory migrant quotas in an even rougher manner than the Baltic countries by clearly and unanimously stating that "any proposal leading to the introduction of mandatory and permanent quota for solidarity measures would be unacceptable" (EurActive 2015), the Baltic countries do not represent the "extreme" case and should not expect to be treated in terms of an "international pariah". In practical terms the security threat associated with the current refugee crisis is linked both to the loss of credibility of the EU in the international arena and to the loss of credibility of the governmental structures in the Baltic countries at the local level in the eyes of their citizens.

The following article will first focus on the arguments why Baltic States have opted for the conservative refugee policy so far and whether it has been in accordance with the their capabilities and resources. It will be followed by the debate whether the ongoing pressure to introduce EU-wide permanent refugee quota could potentially give rise to dissatisfaction in Baltic States, which in turn, could give rise to instability in region. The last part of the article focuses on security risks that might occur due to the pressure from the EU on the member states to impose decisions that do not have broad support at the national level.

\section{How Unexpected and Complicated Is the Current Refugee Situation for Europe and for the Baltic States?}

After the establishment of the Schengen area in Europe in 1995, it was expected that the members of the Schengen regime develop a common policy on external border management and protect external borders. As the current refugee crisis has revealed, some countries such as Greece, Italy and Croatia have not met their obligations, which has led to serious difficulties in other EU member states. An unusually large number of refugees is passing through the EU with the purpose of going to countries that attract refugees with better economic and social conditions

The first signs of the emerging migrant crisis in Europe could be seen already in 2013 and 2014, when the number of first time asylum applications to the EU countries had increased substantially compared to the previous years (see Figure 1). However, during the first eight months of 2015, the number of asylum applicants has increased drastically - whereas in 2008 close to 150000 first-time asylum applications had been received annually, within a single month of June 2015 close to 90000 first-time asylum applications have been handed in (see Figure 2). On the basis of the partial data from Eurostat, the number of applications of a similar category received during the first 8 months of the 2015 in the EU member states has exceeded 530000 persons. For over 70 years, the European countries haven't seen such a drastic number of refugees seeking asylum.

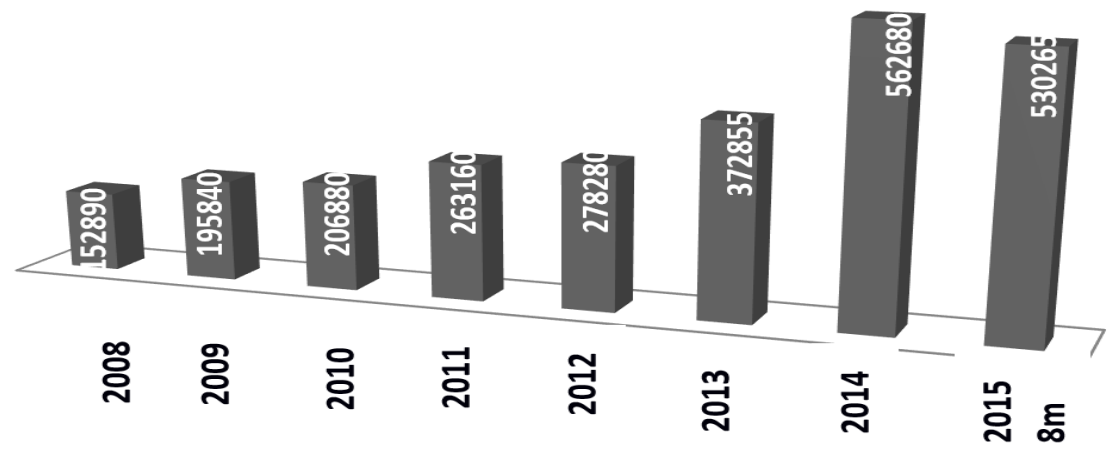

Figure 1. Number of first-time asylum applicants to the EU countries (EU-28) during the period 2008-2015 Source: Eurostat 2015. 


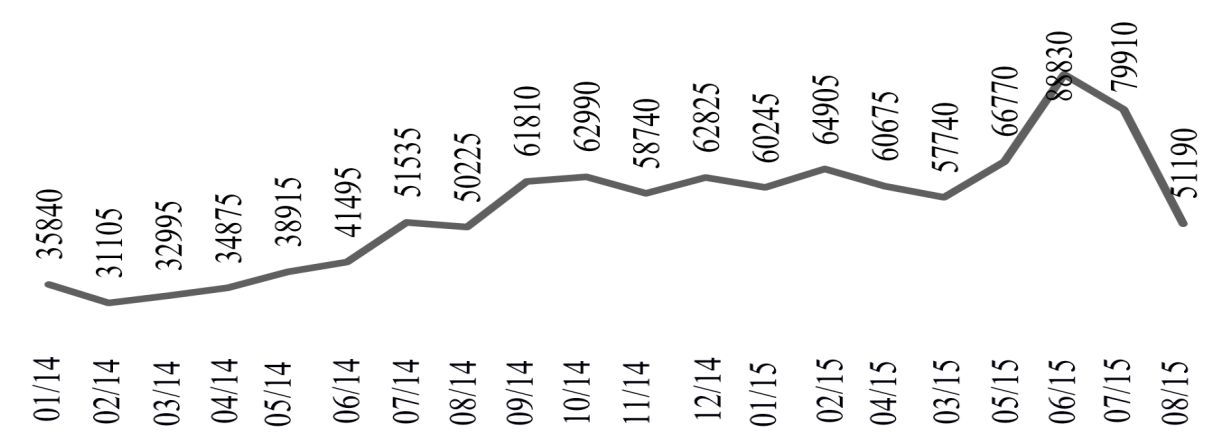

Figure 2. Number of first-time asylum applicants to the EU countries during the period January 2014-August 2015

Source: Eurostat 2015.

About $50 \%$ of the asylum seekers originate from Syria, Iraq, Afghanistan and Albania (see Figure 3), and the main destinations of the asylum seekers were Germany and Sweden (see Figure 4). Next to Germany and Sweden, the burden has been extremely high for Hungary, Greece, Italy, Austria, Croatia and Finland, who had to face massive inflows of refugees wishing to go to Germany and to Sweden. To get the situation under control, Hungary has closed its main border with Serbia, and Germany has introduced temporary border controls on the southern border with Austria, followed by temporary border controls introduced by Austria, Slovakia and the Netherlands. Next to the border control, Hungary has used even more severe measures by classifying unauthorized entry into the country as a criminal offence. Finland has also started border checks on its northern border with Sweden. The current migrant situation in Europe is quite obviously on the verge of getting out of control.

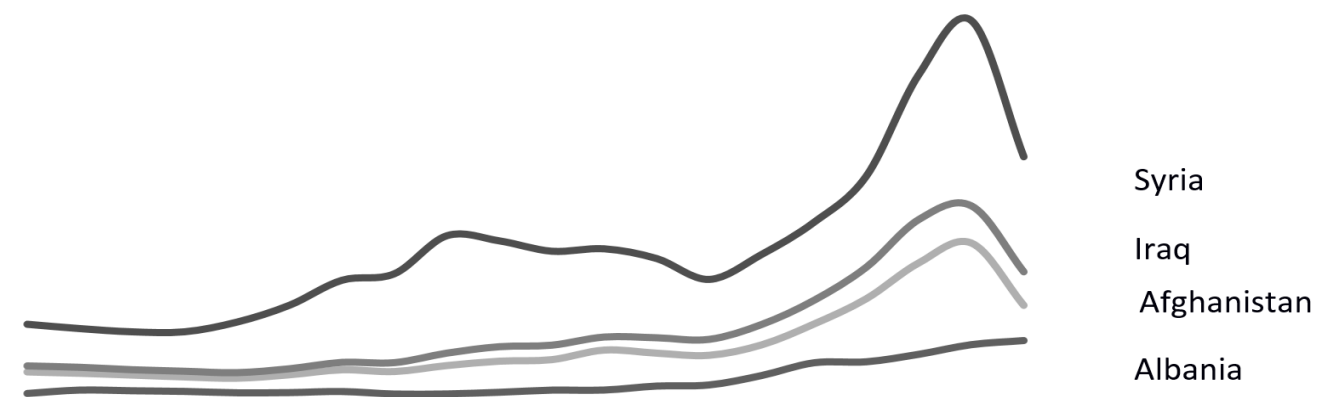

Figure 3. Dynamics of the Europe's refugee crisis: Country of origin of the asylum seekers to the EU countries (EU-28) during the period January 2014-August 2015

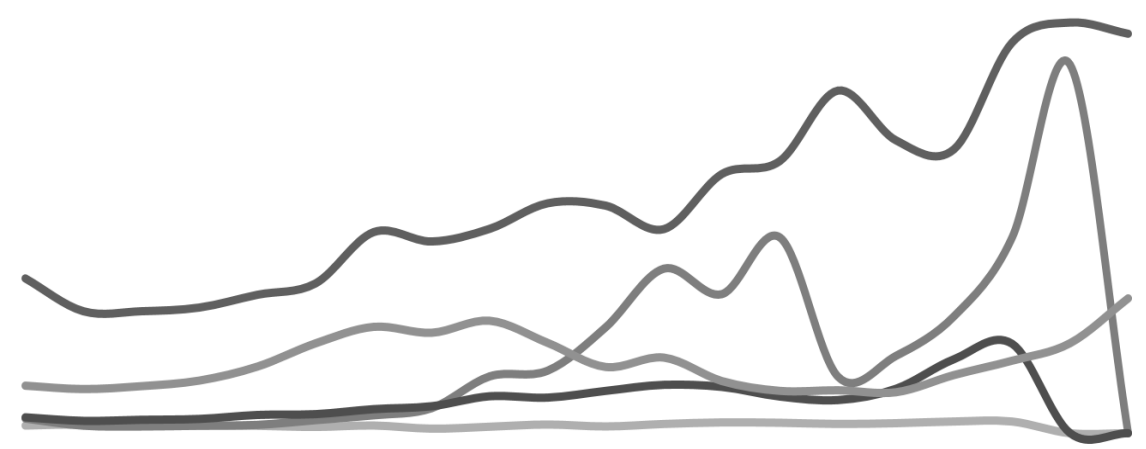

German

Hungary

Sweden

Austria

Greece

Figure 4. Dynamics of the Europe's refugee crisis: EU member states with highest number of first-time asylum seekers during the period January 2014-August 2015 
The migrant pressure on the Baltic countries has been relatively modest compared to their Nordic neighbors, Germany, Hungary or Austria. However, considering the semi-annual data on the first-time asylum applicants, the number of applications has been constantly increasing in Estonia (from 54 in the first half of 2014 to 115 applicants in the first half of 2015)(see Figure 5). The pressure has somewhat weakened in Latvia and Lithuania in the first half of 2015 compared to the second half of 2014. According to the country of origin, Ukrainians, Syrians and Sudanese have dominated among the first-time asylum applicants in Estonia from January 2014 to June 2015, whereas Georgians, Ukrainians and Vietnamese were dominant in Latvia, and Georgians, Ukrainians and Afghans were dominant in Lithuania during the above-mentioned period (authors' calculations based on Eurostat 2015).

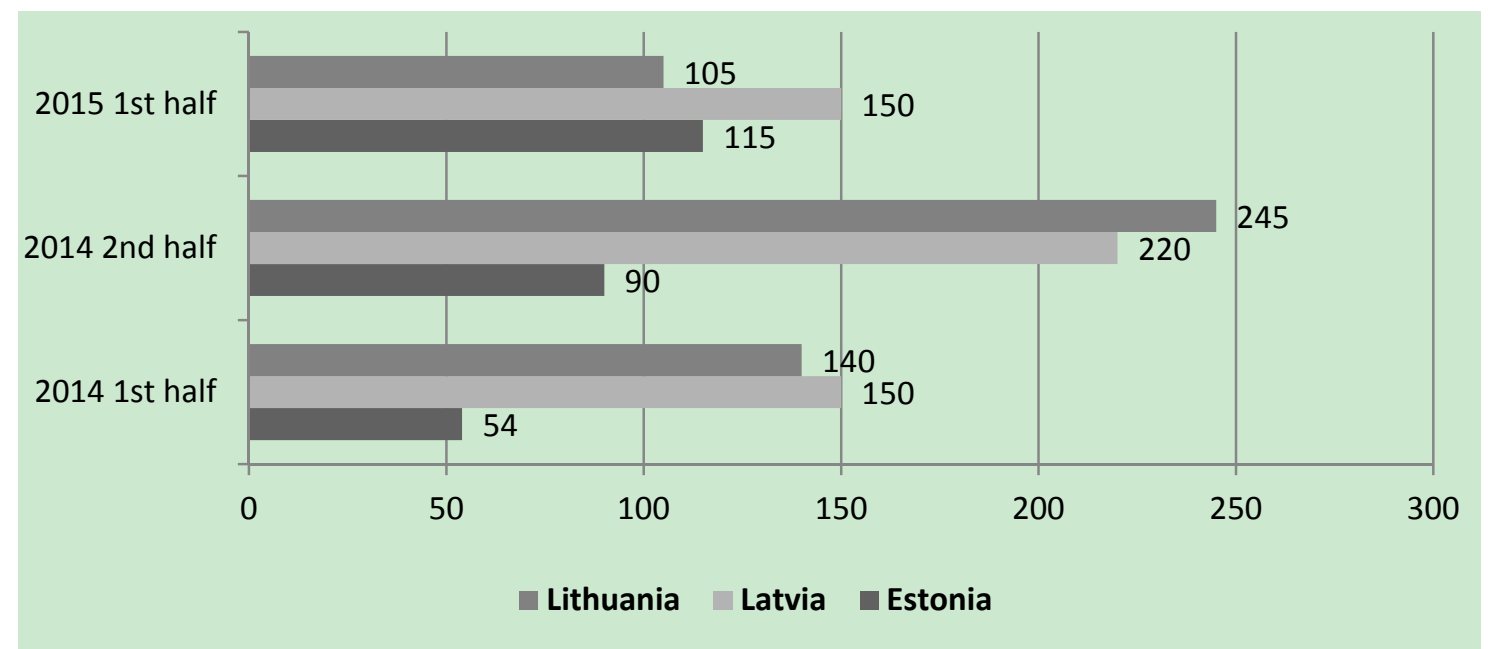

Figure 5. Number of first-time asylum applicant to the Baltic countries during the period January 2014-June 2015 (semi-annual data)

Source: Eurostat, 2015.

The current refugee crisis in Europe is to some extent similar to the situation in 2011 when Italy granted visas in the Schengen framework to tenths of thousands of migrants from the North Africa, including Tunisians who wanted to join their families in France, and allowed them to travel across the Schengen area (BBC 2011). Today, five years later the Schengen countries are facing the same problem in the European Union, but only in a much bigger scale. However, in 2015, efficient solutions are still lacking how to avoid similar situations that have emerged already five years ago. The refugee crisis has clearly revealed the weakness of the European integration model that could lead to the loss of credibility of the EU in the international arena. This could pose a security threat also to Estonia since it has linked its national security with full integration with the European and transatlantic security networks.

Paradoxically, at the European Union level the pressure is put on the countries that have opposed EU refugee quotas, rather than on the member states that have lost control over their, and union's, external borders. After the European Commission for the first time proposed refugee quotas in May 2015, Estonia strongly opposed the intention to oblige all EU member states to share the burden of refugee crisis. To quote the representative of the Estonian Ministry of Interior, Toomas Viks, "The resettlement and relocation of refugees is only one of the possible solutions to express solidarity, but the main way is the financial and technical assistance of other member states./.../ The relocation and resettlement of refugees should remain voluntary for member states." (Postimees 2015a, and The Baltic Course 2015). The Estonian Prime Minister, Taavi Rõivas, did not exclude Estonia's participation in admitting displaced persons, however, he argued that the number on displaced persons should be much less than 326 persons what was suggested initially by the European Commission (Estonian Public... 2015a). Estonian close neighbours, such as Finland, Latvia and Lithuania, have expressed similar views, at that point of time. As suggested by the Estonian Minister of Internal Affairs, Hanno Pevkur, in June 2015, the capability of the country to receive refugees should be taken into account when searching for solutions of the crisis. On the other hand, recent public opinion surveys in Baltic States clearly indicate strong opposition both to the massive influx of refugees in Europe in general and to the decisions taken by the government of Estonia with regard to country's obligations in particular. For example in Estonia according to the survey of EMOR from June 2015, 32\% of respondents were in favour of accepting refugees into Estonia, $42 \%$ of them were against it and $26 \%$ had no 
clear position (Postimees 2015c).

To conclude: as can be seen from the actual data, when the problems in Southern Europe and Germany are getting complicating fast, the actual impact of refugee flows and their proportion to the population in the Baltic States are far from being drastic or posing dramatic security threat. Thus, actual problems tend rather to be dependent on poor strategic communication of the national governments in this matter and insufficient preparedness to receive and integrate arriving refugees.

\section{Can the Baltic States Maintain Their Good Reputation in the Eyes of Voters and International Actors during the Refugee Crisis?}

Europe's refugee crisis has revealed numerous challenges to European integration that could lead to some loss of credibility of the EU in the international arena and pose, thereby, a threat to Baltic States having linked the security of the region with a full integration with the European and transatlantic security networks. As the author sees it, at the EU level the risks could stem from the following sources.

First, the growing influx of refugees into the EU refers to the fact that the EU has lost control over its external borders. This poses a direct security threat to the region. After the establishment of the Schengen area without internal border controls in 1995, it was expected that the member countries develop a common policy on external border management (see, Fact Sheets... 2015). However, as the current crisis has revealed, some countries like Greece or Croatia, intentionally or unintentionally, do not comply with this obligation. This has led to a situation where other EU member states are facing serious difficulties too. A large number of unregistered refugees are passing through the EU with the purpose of arriving at countries, which attract refugees with the fact of having better financial and social conditions. Paradoxically, the current situation is to some extent similar to the circumstances in 2011 when Italy has granted visas in the Schengen framework to tens of thousands of migrants from North Africa, including Tunisians who wanted to join their families in France, and allowed them to travel across the Schengen area (BBC 2011). Now, five years later the Schengen countries are facing the same problem, but only on a much larger scale. Accordingly, what the EU needs is not only need solidarity but also responsibility for trustworthy borders and trust among each other.

Secondly, and rather indirectly, concerns are rising with regard to the growing fragmentation of member states' national interests in terms of refugees and the tendency to protect their own interests. Whether justifiably or not, this often causes additional costs to other member states. Tensions among the member states of the EU are particularly high due to the refugee crisis and they have often accused each other in not following the initial commitments. To bring a recent example, the Hungarian government has accused Croatia for "violating Hungary's sovereignty" and, putting a rhetorical pressure, has asked about the kind of solidarity that allows Croatia to send asylum seekers directly to Hungary instead of honestly making provision for them (Reuters 2015). However, in a wider perspective, the decrease in the solidarity of the EU member states poses a serious security threat both to the region and to the Baltic countries, since it sends a signal to Russia that the EU is not as unified as it pretends to be.

Thirdly, the refugee crisis has also revealed the vulnerability of the EU in economic terms, which also impacts its security capabilities. More precisely, the EU countries have to dedicate significant financial resources to the administration costs of processing asylum applications and offering social guarantees and integration services to a remarkable numbers of refugees. The costs related to the EU-quota migrants from Italy and Greece will be partially covered from the EU budget. However, next to the common budget, majority of the costs are expected to be covered from the member states' own resources. Whereas the "rich" and more advanced EU countries can afford it, as a big proportion of the costs are not country-specific, the "less prosperous" member states like the Baltic ones find themselves discussing with justified skepticism of how to cover the relevant costs from their own limited resources, simultaneously facing worsening demographics and the needs of local population. Higher spending for the increasing number of asylum applicants automatically means that it has to be taken from elsewhere in the countries' own and severely restricted budgets. If the resources will be redirected from those ordinary local services to the services for refugees, it could create frustration at the national level. This is imaginable especially towards the major political figures of the EU who in their speeches stress the need to support refugees, but in real terms do rather relatively little for finding a sustainable and broadly accepted solution to the problem and to control the immigration flows into the EU. As the author sees it, in that regard the European Union together with national governments are risking with the loss of the credibility in the eyes of their own citizens. Particularly, since another intra-EU redistribution of refugees suggested by the European Commission does not represent a sustainable, reasoned and efficient solution to the refugee crisis.

Fourthly, the asylum seekers accepted by the peripheral states would presumably wish to leave for the more 
prosperous Western member states (like Sweden and Germany) and thus cause the infrastructure be relatively over-sized. What is more, and perhaps controversially, the costs for accommodating and integrating the asylum seekers in countries which they will emigrate on the first occasion arising for the absence of well-paid jobs or sufficient social benefits tends not only to see the costs wasted but also to benefit the old member states by adding to their labour ranks. Thus, the economic inequality between the old and new member states will not merely be stressed but be made wider once again. This tendency is bound to make the Union weaker, both in spirit and in tangible terms.

In the long run, current refugee policy will impact also the social and economic conditions in the countries of origin. If some of the EU countries encourage the asylum seekers to come to the EU, they basically pull out the productive labor force from the home countries of asylum seekers. To illustrate the situation, Germany, France and Sweden have welcomed refugees from Albania already since 2012. This has encouraged Albanians to leave the country mostly for economic reasons and due to the overall instability, but not because of direct military conflicts in the region. Although, emotionally, there is perhaps no big difference whether people are dying of hunger or from a bullet. During the first eight months of 2015, more than 42000 Albanians applied for a first time for the asylum in the EU, which makes about $1.5 \%$ of the total population of the country. More than $60 \%$ of the asylum seekers were males, $2 / 3$ of them were 18 to 64 years old. Thus, the most productive part of the labor force has left the country, which, in turn, leaves fewer opportunities for recovery and improving their lives for those people who have stayed in Albania. In this context, part of the responsibility for the consequences of the growing immigration into the EU should be taken by the EU itself, and the union should already now imply measures to diminish possible financial and security risks. In this sense, the lack of long-term visions could cause the loss of credibility in the international arena in the same way the lack of direct financial resources does.

The private sector in Baltic States has taken a pragmatic approach to the relocation of refugees, as some entrepreneurs have publicly announced that they would like to offer some work to the refugees. However, there appears to be rather little interest in doing it that is to some extent understandable in the light of low public support for the relocation of refugees to Estonia. The Estonian Refugee Council has carried out projects in 2012 to increase the participation of refugees in the Estonian labour market and to motivate the employers to offer work to the refugees. However, only a limited number of asylum applicants and persons who qualified for the refugee status are currently working: approximately $21 \%$ of the persons qualified for the refugee status and $11 \%$ of the asylum applicants are currently working (Varjupaigataotlejate... 2015).

To sum up, activities that harm the uniformity of the EU should be avoided and any actions that reduce tensions between the EU member states should be supported. This is vital for the EU to regain its self-confidence in the international arena and to guarantee that the existing commitments among EU member states are respected. As the author sees it, in the context of the current refugee crisis in the EU, the call of the European Commission President, Jean-Claude Juncker, to impose mandatory migrant quotas and the most recent decision based on the qualified majority to impose the quotas despite the resistance of some EU member states, while effective in the short run, could be rather counter-productive in a longer term since the countries that have opposed the quotas are still forced to implement the majority decision without essentially supporting it. Additionally, linking the existing commitments like Schengen or subsidies of structural funds with the readiness to accept new obligations is lowering international and intra-union trust towards the EU institutions and treaties.

In a long term perspective, this makes them question whether European integration in its current shape could cause more harm than good. Since the EU migrant relocation program is, in principle, based on the "push" factor (i.e. refugees are "forced" to resettle to the countries they are not interested in), the measure per se constitutes another security risk to those countries that agreed to allocate migrants, since neither migrants nor permanent residents of the country are interested in integration. Despite the statements that EU mandatory refugee quota are needed to stop "asylum shopping" (for example, by the Dutch Prime Minister, Mark Rutte), it is difficult to see any logic in the migrant quotas. On the one hand, the "voluntary" national migrant quotas apply to the relocation of refugees who have reached Greece, Cyprus and Italy; however, it does not include the main destination countries of the asylum seekers such as Germany and Sweden. One reason behind current pressure of European Commission can also be long-term tradition of successful positive conditionality between European Commission and governments of the Baltic States (Veebel 2009, 208-209). Thus, the asylum seekers are still motivated to come to Germany and Sweden to apply for better financial and social conditions. On the other hand, no reliable mechanism exists that actually guarantees that migrants will stay in the countries they were relocated.

\section{Analysis: Risks to Lose Credibility in the Eyes of Citizens}

Next to the risk of the EU institutions of losing their credibility, also the loss of credibility of governmental 
structures could pose additional threats to the national security in the EU countries, including the Baltic ones. This is particularly relevant in the light of the current migration crisis in the EU, which has, at least, in Estonia clearly revealed the dissatisfaction of the majority of population with the decisions the government has made as regards the relocation of refugees to Estonia. According to the most recent survey from September 2015, only 7 percent of the Estonian population trusts the Prime Minister, Taavi Rõivas, as regards the issues related to the refugee crisis, and only $27 \%$ of the Estonian population does consider government credible on these matters (Pealinn 2015). According to another survey from May 2015 that assessed the work of the government (see, Turu-uuringute... 2015), the support for the Estonian government and the Prime Minister was the lowest among the people living in the eastern part of Estonia, where a large Russian community in Estonia is located. During turbulent times the acceptance of not-so-"voluntary" EU-migration quotas could constitute a trigger that could lead to a serious security crisis in the country.

Paradoxically, in Estonia the security threats are mainly pegged to the failure of the government's communication strategy, rather than previous negative experiences with the refugees. In other words, one could argue that the people are afraid of government's actions rather than the refugees. Due to the lack of communication, the people of Estonia - the voters - have already started to show some doubts about the long-term sustainability of the process. In a long term, it cannot be excluded that the people's dissatisfaction with the management of the current migration crisis at the national level could, at a certain point, be transferred to the reluctance among citizens against the government policies in general. This poses a clear security risk.

To avoid the loss of credibility at the national level, it would be justified to follow the legitimate logic of the process. The immigration of third-country nationals has, until now, clearly been within the competence of the EU member states and not of the EU itself. However, the refugee crisis in the EU has been suddenly defined by the EU-politicians as a matter of common interest and common concern. The EU migration quotas present a major step in transferring the respective competence to the EU in this area. However, as the authors see it, since people have not directly given national governments a mandate to agree with the relocation of refugees from other EU countries, national governments should not delegate the "nonexistent" mandate to the European Commission. The governments of Baltic States should take more initiative and responsibility for the situation at the national level. Local experts believe that the current low support for refugees in Estonia is, besides the escalation of the crisis at the global arena, related to the poor communication of the national government in explaining the underlying causes of its decisions to the public

In practical terms the "existential security threats" at the nation-state level, are associated with the potential loss of credibility and legitimacy of the national governments. In other words, people in Baltic States are afraid of the government's actions and transparency, rather than the refugees themselves. Due to the weak and unfocused strategic communication in terms of refugee crisis, the people of Baltic States have already started to have some doubts about the long-term sustainability of the process. First signs of it are already emerging in the form of loss of credibility of the national government in issues related to the solvency of the current refugee crisis. This could give rise to the increase in instability at the national level that, in theory, involves high risks and hazards to the country's national security. Navigating between necessary EU initiated policy change and public popularity however has been one of the main dilemmas after the EU accession (Pettai and Veebel 2005, 113-114).

\section{Conclusions}

Recent developments starting with the Russia-Ukraine conflict and ending with the economic and political instability in Greece have given rise to instability in Europe. Yet, none of the previous crises could be compared with the crisis concerning the current massive influx of refugees into the EU (now also connected with terrorist attacks), that challenges sovereignty, solidarity and responsibility of the European Union member states. In this context, it is important to understand the actual security threats related to the refugee crisis, particularly for the Baltic countries that have linked their security with European Union and the NATO. In all of the Baltic States, the refugee crisis has been presented as a securitization topic, meaning that the opposition to the EU-migrant quotas has been described as an existential security threat to the country, since it could lead to the country's isolation from the international community, reducing of the EU subsidies, the loss of the NATO security network and its exposure to the security threats from Russia.

The current refugee crisis has clearly revealed, that the EU has no control over its external border and that some EU member states are unable to comply with their obligations or tend to protect their own interests, whether justifiably or not. Instead of focusing to the joint efforts to reinforce Schengen outside borders, member states are focusing to reinstalling internal border controls. Most visible examples of this are fences built by some EU member states (Croatia, Hungary and Slovak Republic) on their borders to stop uncontrolled migration flows. 
Since no long-term vision exists at the EU level how to cope with the migrant crisis, it would be fully justified to ask whether the Baltic countries should also start building fences on their border to prevent security threats caused by refugee influx. However, previously mentioned term "existential security threat" should not be associated with the acceptance or non-acceptance of the EU-migration quotas, but with the overall possible loss of credibility of the EU in the international arena and with the loss of credibility of the national governments at the local level.

As the authors see it, the most complicated issue in giving reason at the local level to the government's decision to accept the EU refugee quota is related to some "over-dramatization" of criticism of the EU core member states towards the Eastern European countries. For example, in Estonia, the politicians of the coalition parties have associated people's willingness to accept refugees with the country's responsibilities towards the NATO partners, using very broad argument "if you want to be protected by the allies, you have to accept refugees". Thus, the refugee crisis has been presented in Estonia as a securitization, meaning that the opposition to compulsory migrant quotas has been "dramatically" described as an existential threat, because it could lead to the isolation of the country from the international community, to the loss of the NATO security network and to exposure to the security threats from Russia. In this light, following the logic of the securitization theory (see, e.g. van Munster 2009, Šulovic 2010, etc.), the migration quotas are justified and should be considered as a priority, since extraordinary countermeasures should be used to handle existential threats. However, in practical terms there is rather little ground for this opinion. To quote principal figures of the NATO, e.g. Sir Adrian Bradshaw, different approach of the allies as regards the refugee crisis does not reduce the contributions of the NATO allies in collective security measures (Postimees 2015f).

In practice, as the authors see it, the dangers that arise from the loss of credibility of the EU and the local governments cannot be combated with the EU-migration quotas and building fences. To restore the confidence in the EU, any activities that harm the uniformity of the EU should be avoided and any actions that reduce the tensions between the EU member states should be supported. In this light, the most recent decision based on the qualified majority to impose the refugee quotas despite the resistance of some EU member states could be rather counter-productive, since this makes them question whether European integration in its current form could do more harm than good. In addition, it difficult to see any logic of how the migration quotas should stop "asylum shopping" since the relocation of migrants does not include the main destination countries of the asylum seekers, such as Germany and Sweden, and the asylum seekers are still motivated to come to Germany and Sweden to enjoy better financial and social conditions. To restore the confidence at the national level, it would be justified to follow the legitimate logic of the processes. As the author sees it, since people have not directly given national governments the mandate to agree with the relocation of refugees from other EU countries, the national governments should not delegate the "nonexistent" mandate to the European Commission.

However, there are several reasons why Baltic States have chosen the conservative line in the refugee policy and has initially opposed the European Commission's idea to relocate refugees from Greece and Italy to Baltic States. Firstly, Estonia, Latvia and Lithuania have insufficient financial resources to offer support for the vulnerable groups among the permanent residents in their territory. It must be admitted, of course, that neither have these countries built a comparable welfare-model to the Scandinavian states on their own level. Combined with uncertain economic times and unclear outlook as regards the solution of the refugee crisis, this is also one of the reasons why public opinion in Baltic States has tended mostly to oppose EU-wide refugee quotas. Secondly, Baltic States lack the experience and "best practices" in integrating ethnic groups that dominate in the current refugee flows in Europe, such as Syrians, Afghans, Albanians and Iraqis. This gives rise to the relevant concern that they may not succeed in integrating the "new" immigrants in their societies. Thirdly, previous experience Baltic States in integrating the "old" immigrants from the Soviet period have been rather discouraging. More precisely, during the Soviet period, Estonia and Latvia faced massive inflows of predominantly Russian-speaking immigrants from other republics of the Soviet Union. Fourthly, pressure of the asylum seekers on Baltic States has been relatively modest in the past, compared to other EU member states, particularly the Nordic neighbors of Estonia, or Germany, Hungary and Austria. This could be also the reason why there were virtually no public debates with regard to the national refugee policy in Baltic societies.

\section{References}

BBC News. (2011, April 26). France and Italy push for reform of Schengen treaty. Retrieved from http://www.bbc.com/news/world-europe-13189682

EurActive. (2015, September 7). Visegrad summit rejects migrant quotas. Retrieved from http://www.euractiv.com/sections/justice-home-affairs/visegrad-summit-rejects-migrant-quotas-317388 
Eurostat. (2015). Data category: Population and social conditions - Asylum and managed migration. Retrieved from http://ec.europa.eu/eurostat/data/database

Fact Sheets on the European Union. (2015). Management of the external borders. European Parliament. Retrieved from http://www.europarl.europa.eu/atyourservice/en/displayFtu.html?ftuId=FTU_5.12.4.html

Pealinn. (2015, September 24). Support to prime minister is only 7 per cent (in Estonian). Retrieved from http://www.pealinn.ee/uudised/uuring-peaministrit-usaldab-vaid-seitse-protsenti-rahvast-n153192

Pettai, V., \& Veebel, V. (2005). Navigating between Policy and Populace: Estonia, its Accession Referendum and the EU Convention. Politique européenne, 15, 113-135. http://dx.doi.org/10.3917/poeu.015.0113

Postimees. (2015a, May 11). Estonia does not support the refugee quota (in Estonian). Retrieved from http://www.postimees.ee/3186005/eesti-ei-toeta-pogenike-vastuvotmise-kohustust-eli-liikmesriikidele

Postimees. (2015b, September 20). NATO: refugee crisis has no impact on collective defence (in Estonian). Retrieved

from http://maailm.postimees.ee/3334497/nato-erimeelsused-randekriisi-osas-ei-mojuta-kollektiivkaitset

Postimees. (2015c, June 26). 42 percent from citizens of Estonia are against refugees. Retrieved from http://www.postimees.ee/3236833/uuring-pagulaste-vastu-on-42-protsenti-eesti-elanikest

Reuters. (2015, September 19). Hungary accuses "lying" Croatia of sovereignty violation. Retrieved from http://www.reuters.com/article/2015/09/19/us-europe-migrants-hungary-sovereignty-idUSKCNORJ0KD201 50919

Šulovic, V. (2010). Meaning of Security and Theory of Securitization. Belgrade Centre for Security Policy. Retrieved from http://www.bezbednost.org/upload/document/sulovic_\%282010\%29_meaning_of_secu.pdf

The Baltic Course. (2015, May 12). Latvia and Estonia to oppose EU refugee quota system. Retrieved from $\mathrm{http} / /$ www.baltic-course.com/eng/legislation/?doc=106034

The Economist. (2015, September 19). Europe starts putting up walls. Retrieved from http://www.economist.com/news/europe/21665032-germany-and-other-countries-reimpose-border-controlseurope-starts-putting-up-walls

Turu-uuringute AS/Market research in Baltics. (2015, May 19). Eesti elanikud annavad peaminister Rõivase tööle hinde $2+\quad$ (in $\quad$ Estonian). Retrieved from http://www.turu-uuringute.eu/eesti-elanikud-annavad-peaminister-roivase-toole-hinde-2/

van Munster, R. (2009). Securitizing Immigration. Palgrave Macmillan. http://dx.doi.org/10.1057/9780230244955

Veebel, V. (2009). European Union's Positive Conditionality model in pre-accession process. Trames, 3/13, $207-$ 231. http://dx.doi.org/10.3176/tr.2009.3.02

Veebel, V., \& Kasekamp, A. (2007). Overcoming Doubts: The Baltic States and European Security and Defence Policy. The Estonian Foreign Policy Yearbook, edited by Andres Kasekamp, Varrak.

Veebel, V., Namm, A., \& Tillmann, T. (2014). Testing the Myths of Transition: Was Estonia Following the Shock Therapy Model and Slovenia Following the Gradualist Model in 1991-2000? Studies of Transition States and Societies, 6(2), 5-21.

\section{Copyrights}

Copyright for this article is retained by the author(s), with first publication rights granted to the journal.

This is an open-access article distributed under the terms and conditions of the Creative Commons Attribution license (http://creativecommons.org/licenses/by/3.0/). 